\title{
TERRORISM AND THE RULE OF LAW: Analysis of International Law Perspectives
}

\author{
Doi: 10.23918/ilic2020.58 \\ Dr. Neville D'Cunha \\ Associate Professor \\ International Relations and Diplomacy Department \\ TISHK International University-Erbil, Iraq \\ neville.dcunha@tiu.edu.iq
}

\section{INTRODUCTION}

\subsection{Background of the Study}

Without doubt, terrorism, especially international terrorism poses a grave danger to the international community. Terrorism also has a hydra effect because it is based on an ideology; as a state responds to terrorist with increasingly-repressive strategies, more people are drawn to the ideology because they see the state as illegitimate. Without any hindsight, "the United States regarded the September 11, 2001 incidents as comparable to a military attack. The law on self-defense was invoked and one response was the invasion of Afghanistan, the State 'hosting' the terrorist movement. The result was the removal of its governing authority (the Taliban). While there are few who cannot understand the motives for the US action, questions do remain about its legitimacy" (Dixon \& McCorquodale 2003: 539). Legally, the demise of the Taliban government of Afghanistan is unusual and may set an unfortunate precedent.

One of the causes for the rise of terrorism is that there is little incentive for state-to-state combat in the twenty-first century, especially among nuclear powers because, "International norms, legal regulations and the treaties have created a situation today where invasion and conquest are not only outlawed, but also actively proscribed through deterrence" (Thompson, cited in United Nations \& World Bank 2018: 12). In this context, it is mandatory on the international community to settle all disputes through legal debate. Legal debate is the process of ostensibly establishing a concrete lawnon-law boundary and a set of objectives, applicable rules to deal with all political issues. Therefore, it is international law that actually sustains the structure of the international political order.

Hence, after two decades, it has become amply clear that the War on Terror unleashed by the U.S. and its closest allies, have irreparably "damaged international law and international institutions, with deeply troubling and even dire consequences for world peace, stability, and the international rule of law" (Sadat 2004: 136). The fight against terrorism was withdrawn from the political agenda to securitization. By characterizing the September 11 attacks as acts of war rather than as terrorism or crimes against humanity, the United States has lost what could have been an extraordinary opportunity to strengthen international legal norms and combat international terrorism.

\subsection{Conceptual Clarifications}

\subsubsection{International Terrorism}

The Global Terrorism Index defines terrorism as "the threatened or actual use of illegal force and violence by a non-state actor to attain a political, economic, religious, or social goal through fear, coercion, or intimidation" (IEP 2019: 6). According to Ballin: "EU Directive (EU) 2017/541 of 15 March 2017 on combating terrorism defines the aim of terrorist crimes as (a) seriously intimidating a population; (b) unduly compelling a government or an international organization to perform or abstain from performing any act; [or] (c) seriously destabilizing or destroying the fundamental political, constitutional, economic or social structures of a country or an international organization" (2018: 1). Conceptually, contemporary terrorism is understood as "an intentional act of violence or threat of violence by a non-state actor" (IEP 2019: 6).

Terrorism, at least ideologically motivated international terrorism since the beginning of this century, is different: different both in its goals and in its methods, which determine each other. Its goal is to undermine trust in the rule of law in a way that is decisive for the future of the affected societies. The methods of international terrorism are effectively directed against the foundations of 
societies based on trust in the rule of law. Bombing, shooting and car attacks on civilians instil fear, fear that goes widely above the statistical risk. Such terrorist attacks deliberately destruct trust, and also appear to delegitimize the very idea that people coming from different ideological, cultural and religious backgrounds can share the public sphere of a democracy under the rule of law.

\subsubsection{Rule of Law (International Law)}

The law as an abstract system of rules establishes the conditions under which people in large societies can live together in peace. Particularly, International law is the body of rules which are legally binding on states in their intercourse with each other. These rules are primarily those which govern the relations of states, but states are not the only subjects of international law. International organizations and, to some extent, also individuals may be subjects of rights conferred and duties imposed by international law. There is increasing acceptance that the rules of international law are the foundation upon which the rights of states rest, and no longer merely limitations upon states' rights which, in the absence of a rule of law to the contrary, are unlimited. Jennings \& Watts states: "Furthermore, international law may now properly be regarded as a complete system. By this is meant not that there is always a clear and specific legal rule readily applicable to every international situation, but that every international situation is capable of being determined as a matter of law, either by the application of specific rules where they already exist, or by the application of legal rules derived, by the use of known legal techniques, from other legal rules or principles" (cited in Dixon \& McCorquodale 2003).

While international law is of a different nature to national law in its sources, institutions, and development, international law is 'law' in that it seeks to ensure that there is order and structure in the international community. This order enables the members of the international community to interact together with a reasonable degree of confidence and ensures that changes in rules generally occur by a coherent and consistent process.

\subsection{Research Objectives and Questions}

The objective of this article is to engage in a discursive critique of the War on Terror discourse. Specifically, it aims to describe and dissect the grave threat to International law-based Rule of Law paradigm by International terrorism and, more precisely Warfare-based counter-terrorist measures. With these objectives in the forefront, this article is organized in three main parts as to address three major questions: (i) How the War on Terror has affected some of the basic principles of International Law-based International order over the past two decades? (ii) What are the differences and similarities between Warfare and Lawfare based counter-terrorism strategies? (iii) How can counter-terrorism measures and strategies based on the integration of Warfare and Lawfare be an effective global response to international terrorism?

\subsection{Limitations and Significance of the Study}

Without pretending to be an international terrorism or international law scholar or analyst, I wrote this article as a student of international relations and diplomacy with special interest in Kurdistan and Iraq. It is about how War on Terror has altered the world in which we live. What the discerning reader will find in this paper is not a comprehensive and in-depth analysis of the causes and consequences of international terrorism or technical discussion of counter-terrorism strategies grounded in the rule of law especially international law adopted by governments. Rather they will find here philosophical reflection on how International Law (Rule of Law) can reestablish the international order that has been disordered by the War on Terror. The issues discussed here are serious; they are shared by scholars and civilians worldwide. The Rule of Law principles at stake are universal ones. If this introductory article can raise awareness of the importance of defending the Rule of Law principles being undermined by the War on Terror, I would consider this to be a worthy contribution.

\section{METHOD}

The analytical approach employed in this study falls broadly under the mantle of discourse analysis (Jackson 2007). A form of critical theorizing, discourse analysis aims primarily to illustrate and describe the relationship between textual and social processes. Broadly speaking, this understanding of language as constitutive or productive of meaning; an understanding of discourse 
as structures of signification that construct social realities, particularly an understanding of discourse as being productive of subjects authorized to speak and act, legitimate forms of knowledge and political practices and importantly, commonsense within particular social groups and historical settings.

On this epistemological foundation and adopting an interpretive logic rather than a causal logic, the discourse analytic technique employed in this article proceeded in two stages. The first stage entailed a close examination of texts representative of the 'Terrorism-International law' discourse, particularly those by actors presumed to be authoritative or authorized speakers of the dominant discourse. As such, the primary units of analysis or 'data' for this research were written and spoken English-language 'Western' texts authored primarily between 2003 and 2019, including: (1) official speeches and documents of senior policy makers; (2) books, articles and reports by major thinktanks, public intellectuals and journalists; and (3) academic books and articles from terrorism and international relations/legal journals. Each text was examined for the labels, assumptions, narratives, predicates, metaphors, inferences and arguments they deployed and the kinds of existing cultural-political narratives and pre-existing texts they drew upon.

The second stage of the research involved subjecting the findings of the textual analysis to both a first- and second-order critique. A first-order or immanent critique uses a discourse's internal contradictions, mistakes and misconceptions to criticize it on its own terms and expose the events and perspectives that the discourse fails to acknowledge or address. The point of this form of internal critique is not necessarily to establish the 'correct' or 'real truth' of the subject beyond doubt, but rather to destabilize dominant interpretations and demonstrate the inherently contested and political nature of the discourse. A second-order critique entails reflecting on the broader political and ethical consequences - the ideological effects - of the representations enabled by the discourse. Specifically, it involves an exploration of the ways in which the discourse functions as a 'symbolic technology', wielded by particular elites and institutions, to: structure the primary subject positions, accepted knowledge, commonsense and legitimate policy responses to the actors and events being described; exclude and de-legitimize alternative knowledge and practice; naturalize a particular political and social order; and construct and maintain a hegemonic regime of truth. A range of specific discourse analytic techniques are useful in second-order critique: genealogical analysis, predicate analysis, narrative analysis and deconstructive analysis. Importantly, the exposure and destabilization of dominant forms of knowledge opens up critical space for the articulation of alternative and potentially emancipatory forms of knowledge and practice.

\section{FINDINGS}

In this section, I present the analysis on issues pertaining to the intersection of terrorism and international law. The aim is to present the texts referring to the many dimensions of the dominant discourses. However, the approach is selective. The Discourse Analysis (DA) is not exhaustive but limited to the sources specifically chosen for this work. The DA of the data led to the emergence of a number of common themes that are central to this study. The key emerging themes are presented as follows:

- New Wars are the wars of the era of globalization. Typically, they take place in areas where authoritarian states have been greatly weakened as a consequence of opening up to the rest of the world. In such contexts, the distinction between state and non-state, public and private, external and internal, economic and political, and even war and peace are breaking down. Moreover the breakdown of these binary distinctions is both a cause and a consequence of violence. New wars can be described as mixtures of war (organized violence for political ends), crime (organized violence for private ends) and human rights violations (violence against civilians). There has been widespread criticism of the term War on Terror because it implies a military response to terrorist violence when policing and intelligence methods, it is argued, would be more effective (Kaldor 2013).

- As large-scale interstate conflicts - the dominant type of warfare in the first half of the 20th century - continues to decrease, states resort to different forms of using force. Developments in the 
last two decades appear to underpin a global interventionism characterized by small-scale, so-called 'precision' strikes, limited ground troop engagement, but long-lasting military operations. Such practices have shaped Western security policy in the global War on Terror, leading to an often limited but seemingly never-ending use of violent force in the Global South. There is also a deepseated asymmetry between Global South and Global North in the context of combatting conflicts in Global South. A Western-focus on terrorism risks often neglects the contributions of Global South countries in shaping the terrorism agenda (Bode \& Huelss 2019).

- Security crises pose fundamental challenges to the constitutional structure of liberal governments. Unexpected security dangers such as catastrophic terrorist attacks serves as a reminder that collective security is a precondition for the proper functioning of a liberal order. When the security of the nation is at stake, it becomes difficult to argue that the executive be bounded by [international law] that might hamper its capacity to ensure collective security. Under such circumstances, in fact, the citizens themselves will likely view a rigid adherence to legal limits as problematic (Dragu \& Polborn 2014: 511). Scholars have argued that executive discretion is essential to respond effectively to terrorist activities, and thus the executive should be afforded legal flexibility to thwart security dangers (Paulsen 2004; Posner 2006; Tushnet 2005 cited in Dragu \& Polborn 2014: 512). On the contrary, Dragu \& Polborn found "that some legal limits on executive counterterrorism powers can be beneficial on security grounds alone, and, therefore, strengthening institutions that uphold the rule of law in the fight against terrorism can be effective way to achieve security from terrorism" (2014: 512).

- Counter-terrorism (CT) measures need to undermine the legitimacy, credibility and appeal of violent extremists, for instance, by highlighting their involvement in criminality; explaining how judiciary systems can be used to reduce grievances within a community; ensuring that polarizing social, political, or other issues are contained (Horgan 2014 citied by Sinai, Fuller \& Seal 2019). Finally, the measures used by governments in responding to the terrorist threats facing them are crucial in determining the effectiveness of their CT measures. According to Bosi, Demetriou, and Malthaner (Eds., 2014 cited by Sinai, Fuller \& Seal 2019) certain governments respond in a primarily coercive way to outbreaks of violent extremism. To avoid such ineffectual government responses because of their inability to control such adversaries, several authors recommend..."dialing down" their rhetoric, viewing terrorism as ordinary crime, accepting uncertainty, maintaining civil liberties, and not over-militarizing their response (English 2009; Gomis 2016; Jackson 2018; Kurzman 2011; Richardson 2007; Sageman 2016; Sageman 2017; Shemella 2011; Tembo 2015 cited by Sinai, Fuller \& Seal 2019).

- It would be too easy to suggest that we can understand the attacks on 11 September 2001 as the birth of a new terrorism. But the day does mark a point of rupture. International law, as a discipline, tends to focus on crises. The response to the 11 September 2001 attacks has prompted crises in international law and politics. One consequence has been the rise of trans-nationalization of counter-terrorism law. This law entails the closing of the gap between law on international peace and security (e.g. UN Security Council resolutions) and national laws on substantive and procedural criminal law and criminal justice. It also entails, as well as constitutional and administrative law, immigration and asylum law, and other fields. In his book, Terror and Consent, Philip Bobbit makes several assertions about the relationship between terrorism and the law: Bobbit's assertion is more persuasive if we understand it as a claim that terrorism stands against the idea not of lawful activities per se, but of lawfulness, i.e. of compliance with the rule of law. Terrorism, even terrorism against criminals, is anathema to the rule of law. The rule of law pursues certainty in government, and often on other values of government. Terrorism, by definition, seeks to instil fear so as to communicate its message. It tends to involve unpredictable acts of violence, not behavior that complies with legal or social rules. As such it stands against lawfulness (Murphy 2019).

- First of all, combatant and non-combatant are defined in the 1949 Geneva Convention. A combatant is allowed to kill. A non-combatant is not. So if you are in an armed force, if you wear a uniform, if you are subject to command, if you carry your arms openly as specified in the Geneva Conventions and you are captured, you are entitled to prisoner of war status. If you do not meet 
those standards you are not a combatant; you may be a fighter, but you are a criminal. A battlefield is not a tourist destination - though it may be. The subject matter here is the relevancy of the laws of war in light of the hostilities taking place in Syria, Iraq, and elsewhere. These laws are divided into three categories known by their Latin names as, jus ad bellum, jus in bello, and jus post bellum. The first category delineates the framework and circumstances under which the initiation of war or use of force is justified. The second category deals with the limitation imposed upon the methods and means used in the prosecution of war or in the use of force. And the third category focuses on issues that postdate the ending of hostilities. The Kellogg-Briand Pact of 1928 explicitly condemns and renounces the recourse to war as an instrument of national policy. The Charter of the United Nations further requires in Article 2(4) that all member countries refrain from the threat or use of force against other states. I am going to speak only about one issue, and that is whether terrorism can be treated as an international crime - like war crimes, genocide, and crimes against humanity. In 1937, the League of Nations adopted the first multilateral convention for the prevention and punishment of terrorism. Article 1 of that convention defines acts of terrorism as "criminal acts directed against a state or intended to create a state of terror in the minds of particular persons, or a group of persons, or the general public." What al-Qa'ida has done through terrorism has highlighted the tensions between protecting civil liberties and protecting the nation. And we do not have a good response. What you see at Guantanamo Bay is a question of whether these captured individuals should be treated as criminals or as enemy combatants. We have not resolved that one way or the other. Second, the best armies, navies, air forces, and marine corps are incapable of defeating an ideological enemy that has no army, navy, air force, let alone a marine corps. We see that in Afghanistan, we see that in Iraq, and we see that with the Islamic State (Alexander 2017a).

- The temptation to jettison legal constraints is understandable when faced with a hostile enemy that does not itself obey the law. Perhaps there are times when law fails, or when civil disobedience is appropriate if law itself becomes illegal or immoral. But the attacks of September 11th did not present such a case. Indeed, the hideousness of the acts themselves so shocked the international community that they provided a unique opportunity to strengthen a growing international consensus condemning attacks on civilians whatever the motivation. This is not to suggest that a military response was necessarily illegal under the circumstances, only that any military actions taken must, to be effective in the long term, employ force in service of the rule of law. Viewing the antiterrorism campaign in Afghanistan as an international criminal law enforcement operation, rather than an act of retribution would also have created a positive precedent for future cases. There may be a place or even a need for the use of force in response to the deadly acts of international terrorists, but military power must be employed judiciously and subject to the constraints of international law (Sadat 2004).

- Although the Justices are committed to the rule of law and the protection of the Constitution, they also see themselves as responsible for protecting the interests of the nation they serve. The Justices are practical people. So they search for ways to honor the Constitution without compromising vital national interests. What is missing from this calculus, and in my judgment however, is a full appreciation of the value of the Constitution - as a statement of the ideals of the nation and as the basis of the principle of freedom - and even more, a full appreciation of the fact that the whole-hearted pursuit of any ideal requires sacrifices, sometimes quite substantial ones. It is hard for the Justices, or for that matter anyone, to accept that we may have to risk the material wellbeing of the nation in order to be faithful to the Constitution and the duties it imposes. Still, it must be remembered that the issue is not just the survival of the nation-of course the United States will survive - but rather the terms of survival (Fiss 2006).

- Dunlap's concept of - lawfare was straightforward: He defined it as - the use of law as a weapon of war, later clarifying that it involved - a strategy of using — or misusing — law as a substitute for traditional military means to achieve an operational objective. Thus, the Bush Administration suggested that - lawyers who defend their clients, or who present their claims to domestic or international courts, might as well be terrorists themselves. In short, - lawfare, as defined by Bush Administration officials, is a terrorist tactic. Rather than utilizing the term to discredit an 
opponent's reliance on law and legal processes, the alternative definition of -lawfare focuses on as a kind of -critical self-reflection\| on the relationship between law and war, asserting that - lawfare can be used to describe the - art of managing law and war together (Waters 2010). Lawfare can operate as a positive "good." Ideally, substituting lawfare methodologies for traditional military means can reduce the destructiveness of war, if not its frequency. Military lawyers seem to conceive of the rule of law differently [than civilian government lawyers]. Instead of seeing law as a barrier to the exercise of the client's power, these attorneys understand the law as a prerequisite to the meaningful exercise of power. Law makes just wars possible by creating a well-defined legal space within which individual soldiers can act without resorting to their own personal moral codes (Dunlap 2008).

\section{DISCUSSION}

The purpose of this study was to investigate the ways in which International Law perspective discourses shape the worldview of scholars in dealing with terrorism, especially international terrorism. The scholars whose discourses I analyzed were committed to prioritizing International Law in combating international terrorism. Through their robust scholarship, they have put forward convincing arguments that present International Law as the best alternative to deal with complex forms of international terrorism.

The analysis of the overall international terrorism discourses within the scope of this study revealed important differences in how the various scholars perceive international terrorism. If Mary Kaldor (2013) terms it as forms of New Wars in which non-state armed groups conduct warfare with various States, the dissenting voices think otherwise; notably among them are Sadat (2004) and Bergeron (2013) who disagree strongly with Kaldor. They term international terrorism as organized crime. Any discussion of the relationship between organized crime and international terrorism will necessarily depend on what one means by those terms. A major problem in conceptualizing the relationship between crime and terrorism is that both concepts are essentially opaque; they deal with apparently different subject matters and yet also share much in common. This opacity and the political complexity it generates partly explain why the global community still lacks a common definition of both organized crime and terrorism.

The analysis further revealed that international terrorism rather than uniting the Global North with the Global South had actually created unbridgeable gulf between them especially on ideological grounds (Bode \& Huelss 2019). The Western powers without taking the developing nations into confidence has termed international terrorism as a security problem rather than international law issue. Hence, rather than strengthening multilateralism in combatting international terrorism, the United States and its closest Western allies acting unilaterally have actually weakened the international order as well as undermined the status of International Organizations like the United Nations as well as violated International Conventions and treaties.

Through further analysis, I found a striking difference in approaching international terrorism as International law issue rather than security issue. Most scholars underscored the fact that terrorists should be handled as criminals rather than combatants (Sinai, Fuller \& Seal 2019; Sadat 2004; Bergeron 2013; Murphy 2019; Dragu \& Polborn 2014; Ballin 2018). This way the legitimacy that has been unnecessarily bestowed on them can be stripped. Criminality of the terrorists has to be placed before all stakeholders and they should be dealt with lawfully rather than exterminating them through political violence. It has to be noted that international law does not give any party the legitimacy to practice violence. Hence by putting the state and the terrorist on par it can go a long way in bringing justice into play. This way the trust in the rule of law can be reclaimed (Ballin 2018) that has been severely damaged due to the War on Terror.

The analysis of the discourse of Alexander (2017a) illustrates the dark side of the War on Terror. The misadventure of United States in Afghanistan and Iraq has clearly shown that warfare cannot win a war between two unequal enemies. While the United States had the best resources at its disposal yet it could not combat the ideology of the terrorists. Hence, the United States has come under the scanner for violations of human rights and mass atrocities. All this would indicate that an 
emphasis on international law and law enforcement (Sadat 2004) with the help of the entire global community might be a key element in combatting international terrorism in the future.

At the same time, it has to be noted that rule of law has its own severe limitations. The judiciary responsible to adjudicate and implement laws might be severely constrained by the national interests of the affected States (Fiss 2006). The judiciary might be compelled to give biased judgments that might infringe the principles of justice. These contrasting developments highlight the complex nature of the relationship between security, national interests and the rule of law. Hence, there is always a danger that law can be misinterpreted and even jettisoned.

At the end of the day, the entire discourse on putting into practice the rule of law in combating international terrorism has its own challenges. On one hand, the states face a host of complex issues in the face of terrorism like the safety of its citizens, the very survival of the state and the pressures of international community, the terrorists on the other hand have no such constraints or limitations. The very act of terrorism is to undermine lawfulness (Murphy 2019). Dunlap (2008) and Waters (2010) propose a very different and most creative solution. They recommend an integrated approach where warfare and lawfare are together put in service of combating international terrorism. The most important part of this endeavor is that lawfare is the primary element while warfare is the secondary element. The most important part is that the response of the security agencies is constantly monitored and controlled by the norms and values set by international law. The terrorists if and when apprehended are treated as criminals and dealt according to the rule of law. The terrorists are given all resources to defend their cases and will be incarcerated as ordinary criminals.

\section{CONCLUSION}

So, given that terrorism and extremism aims to affect us internationally, it goes without saying that in order to be successful in combating terrorism, we have to have international cooperative structures in place to identify these organizations, to identify their leadership and their aims; to be able to cut off funding and supplies and support to them; and to be able to stem the flow of new recruits (Alexander 2017b). Therefore, this discourse analysis findings proved that international law should be the cornerstone of the international community's strategy to combat international terrorism across the world. As the world take stock of two decades old War on Terror, there is a pressing need to identify areas where lawfare and warfare can be integrated to prevent or counter international terrorism. In a world that will battle for a long time the menace of terrorism, it is high time that States update their beliefs and thus influence their decisions to incorporate international law within security operations in dealing with international terrorism.

Taking my findings further, I suggest, the ICC (International Criminal Court, the Court) does have the potential to become a Court that provides international justice and peace. It is a court with an ethical aim, that is, the prosecution of criminals, and it is gaining in legitimacy. It could attract states which want to show their support for the defense of human rights. The work of the ICC could create a long-term deterrent effect, that is, potential criminals could fear the consequences of their acts, especially once they are no longer in positions of power. It is also argued here that the contribution of the ICC to justice and peace depends on its institutional autonomy to indict potential criminals, on the support it receives from states parties to the ICC, on its own impartial work, and on the extent to which it is respected by people in the world. The credibility of the ICC is linked to its capacity to provide universal criminal justice without bias. This credibility would increase if the ICC could: 1) act independently from states; 2) investigate criminals on all continents, whether state officials or not; 3 ) have the means to deliver justice in a fair way and in a short period of time; and 4) where possible, defer prosecutions at the local level (Gegout 2013). Finally, the ICC must be considered a legitimate actor by all those who have reason to fear indictment, by indicted persons and their supporters, and by the general population in areas where serious crimes are being committed.

The findings are encouraging for establishing the rule of law in tackling international terrorism, but also highlight crucial challenges. If individual states exposure to international terrorism is such a strong factor in willingness to abide with the rule of law, international law may have the opportunity to uphold the rule of law, even in situations where negative attitudes towards rule of 
law should be deeply entrenched. Unfortunately, the integrated performance of lawfare and warfare has fallen short of expectations in many security operations around the world. Episodes of violations of laws, lackluster provision of rule of law in combating international terrorism and inefficient judicial activities in dealing with captured terrorists are common and are quickly noticed by global media as well as civilians. The findings finally suggest, that improving global cooperation among states based on the norms and values of international law, security activities undertaking within the supervision of the tenets of the rule of law and respectful treatment of captured terrorists is a powerful way to help accomplish in renewing, regaining and reestablishing trust in the rule of law.

\section{References}

Alexander, Y. (2017a). Terrorism and the Rule of Law: Selected Perspectives. Available from www.terrorismelectronicjournal.org; www.iucts.org.

Alexander, Y. (2017b). The Role of Diplomacy in Combating Terrorism. Available from www.terrorismelectronicjournal.org; www.iucts.org.

Ballin, E.H. (2018). Restoring trust in the rule of law. ASSER research paper 2018-01.

Bode, I. \& Huelss, H. (2019). Introduction to the Special Section: The Autonomisation of Weapons Systems: Challenges to International Relations. Global Policy, Vol. 10. Issue 3. September.

Bergeron, J. (2013) Transnational Organised Crime and International Security. The RUSI Journal, 158:2, 6-9.

Dixon, M. \& McCorquodale, R. (2003). Cases \& Materials on International Law. (4 ${ }^{\text {th }}$ Edn.). Oxford: Oxford University Press.

Dragu, T. \& Polborn, M. (2014). The Rule of Law in the Fight Against Terrorism. American Journal of Political Science, Vol. 58, No. 2 (April), pp. 511-525.

Dunlap, C.J. (2008). Lawfare Today: A Perspective, Yale Journal of International Affairs. https://scholarship.law.duke.edu/cgi/viewcontent.cgi?article=5892\&context=faculty_scholarship.

Fiss, O. (2006). The War Against Terrorism and the Rule of Law. Oxford Journal of Legal Studies, Vol. 26, No. 2 (2006), pp. 235-256.

Gegout, C. (2013) The International Criminal Court: limits, potential and conditions for the promotion of justice and peace. Third World Quarterly, 34:5, 800-818.

Institute for Economics \& Peace (IEP). (2019). Global Terrorism Index 2019: Measuring the Impact of Terrorism, Sydney, November 2019. Available from: http://visionofhumanity.org/reports (accessed 04-03-2020).

Jackson, R. (2007). Constructing Enemies: Islamic Terrorism' in Political and Academic Discourse. Government and Opposition, Vol. 42, No. 3, pp. 394-426.

Kaldor, M. (2013). In Defence of New Wars. Stability, 2(1): 4, pp. 1-16.

Murphy, C.C. (2019). Terrorism and Transnational Law: Rules of Law under Conditions of Globalisation. Available from: bristol.ac.uk/law/research/legal-research -papers.

Sadat, L.N. (2004). Terrorism and the Rule of Law. Washington University Global Studies Law Review, Vol. 3:135.

Sinai, J., Fuller, J. \& Seal, T. (2019). Effectiveness in Counter-Terrorism and Countering Violent Extremism A Literature Review. Perspectives on Terrorism, Vol. 13, No. 6 (December), pp. 90108.

United Nations and World Bank. (2018). Pathways for Peace: Inclusive Approaches to Preventing Violent Conflict. Washington D.C. World Bank.

Waters, M. A. (2010). "Lawfare" in the War on Terrorism: A Reclamation Project, 43 Case W. Res. J. Int'l L.327. Available at: https://scholarlycommons.law.case.edu/jil/vol43/iss1/20.

\section{Abstract}

Aim: The purpose of this academic undertaking is to focus on the interface between terrorism and the rule of law. More precisely, this paper posits on the role of international law in shaping and implementing counter-terrorism strategies. But some facts must be understood in discussing terrorism and counter-terrorism as there are different varieties of terrorism. Terrorism comprises multi-level kinds of conduct. Terrorism is, however, essentially criminal acts that threaten 
individuals or a populace for the purpose of achieving some political objective. The dangers posed by terrorists to international peace and order needs tactical and strategic responses to combat them on national and global levels. Hence, the law of war and particularly Geneva Convention are addressed, as is the background international law of jus ad bellum, jus in bello and jus post bellum. Methodology: The analytical approach employed in this study falls broadly under the mantle of discourse analysis. On this epistemological foundation and adopting an interpretive logic, the discourse analytic technique employed in this article proceeded in two stages. The first stage entailed a close examination of texts representative of the 'Terrorism-International Law' discourse, particularly those by actors presumed to be authoritative or authorized speakers of the dominant discourse. As such, the primary units of analysis or 'data' for this research included: (1) official speeches and documents of senior policy makers; (2) books, articles and reports by major thinktanks, public intellectuals and journalists; and (3) academic books and scholarly articles in the core terrorism studies and international law. The second stage of the research involved subjecting the findings of the textual analysis to interpretation. It examined how terrorism and international law relate to each other and the challenges they pose for each other.

Outcomes: Emerging from the data were specific themes that are central to this study. First, international law matters in the foundational way of setting up the institutions, the organizations, and the procedures through which states communicate and create counter-terrorism strategies. Second, international law matters in the sense that it creates legitimacy. It creates sense of expectations and reliance about how terrorism will be handled, and that factors into the reputation of states; it affects their calculation of self-interest. And finally, most importantly, international law matters because it creates rules about how states should behave with each other in the event of interstate terrorism, including the most fundamental matters of jus ad bellum and jus in bello. It tells states what they can and cannot do in a number of the most important circumstances. In conclusion, what I say about the pervasive nature of terrorism is that law is not only relevant, it becomes most relevant in these trying circumstances. These times of transition and trauma can offer an opportunity to strengthen international legal norms and combat international terrorism.

Keywords: Rule of law, Global Terrorism, International law, International Conventions 